\title{
Edukasi Bahaya Aborsi Melalui Layanan Whatsapp dalam Meningkatkan Pengetahuan dan Sikap Remaja Putri di SMA Negeri 3 Palu
}

\author{
Hastuti Usman ${ }^{1 *}$, Siti Hadijah Batjo ${ }^{2}$ Nur Rista $^{3}$ \\ 1. Prodi DIV Kebidanan Poltekkes Palu \\ 2. Prodi DIV Kebidanan Poltekkes Palu \\ 3. Mahasiswa Prodi DIV Kebidanan Poltekkes Kemenkes Palu \\ *Email Korespondensi: firel.family@gmail.com
}

\begin{abstract}
Abstrak
Aborsi di Indonesia dilakukan oleh 2 juta orang tiap tahun, dari jumlah itu 70.000 dilakukan oleh remaja putri yang belum menikah. Tujuan penelitian ini adalah diketahuinya pengaruh edukasi tentang bahaya aborsi melalui layanan whatsapp terhadap peningkatan pengetahuan dan sikap remaja putri pada kelas X dan XI di SMA Negeri 3 Palu. Penelitian ini merupakan pre eksperimen dengan desain one group pretest-postest. Besar sampel 86 responden, dengan teknik stratified proportional random sampling. Penelitian dilakukan selama 3 minggu dengan memberikan kuesioner hari pertama untuk mengukur pengetahuan dan sikap siswi lalu dilakukan edukasi melalui layanan whatsapp kemudian hari terakhir dilakukan posttest. Analisis uji statistik menggunakan uji wilcoxon dan diperoleh nilai $\rho$ sebesar $0,000(\rho<0,05)$ serta peningkatan nilai rata-rata sebelum dan sesudah diberikan edukasi sebesar 6,4. Pengaruh edukasi terhadap peningkatan sikap juga dianalisis menggunakan wilcoxon dengan nilai $\rho$ sebesar $0,000(\rho<0,05)$ dan peningkatan rata-rata sikap sebelum dan sesudah edukasi sebesar 1,4. Kesimpulan bahwa ada pengaruh edukasi tentang bahaya aborsi melalui layanan whatsapp terhadap peningkatan pengetahuan dan sikap remaja putri di SMA Negeri 3 Palu. Disarankan untuk memberikan edukasi yang continue untuk siswi di SMA Negeri 3 Palu.
\end{abstract}

Kata Kunci: Edukasi, Bahaya Aborsi, layanan whatsapp, Remaja Putri

\section{Abortion Hazard Education Through Whatsapp Services in Increasing Knowledge And Attitude Of Young Women in SMA 3 Palu}

\begin{abstract}
Abortion in Indonesia is carried out by 2 million people each year, of which 70,000 are made by unmarried girls. The purpose of this study is to know the effect of education on the danger of abortion through whatsapp service to increase the knowledge and attitude of girls in class $X$ and XI in SMA Negeri 3 Palu. This research is a pre-experimental with the design of one group pretest-posttest. With a sample size of 86 respondents, using the stratified proportional random sampling technique. The study was conducted for 3 weeks by giving questionnaire in the first day to measure the students' knowledge and attitudes and then conducted an education through whatsapp service afterward the last day was posttest. Analysis of statistical tests used the wilcoxon test and obtained $\rho$ value of 0.000 ( $\rho$ $<0.05)$ and an increase in the average value before and after being educated at 6.4. The effect of education on increasing attitudes was also analyzed using wilcoxon with $\rho$ value of $0.000(\rho<0.05)$ and an increase in the average attitudes before and after education amounted to 1.4. The conclusion there is an educational effect about the danger of abortion through whatsapp service to increase the knowledge and attitude of girls in SMANegeri 3 Palu. It is recommended to provide continuing education for female students in SMA 3 Negeri Palu.
\end{abstract}




\section{PENDAHULUAN}

Aborsi diindikasikan merupakan masalah masyarakat karena memberikan dampak pada kesakitan dan kematian ibu. Penyebab utama kematian ibu hamil dan melahirkan adalah perdarahan, infeksi dan eklamsia, namun sebenarnya aborsi juga merupakan salah satu penyebab kematian ibu, hanya saja muncul dalam bentuk komplikasi, perdarahan dan sepsis. Hal ini merupakan indikasi bahwa hingga saat ini aborsi masih merupakan masalah kontroversi di masyarakat. Angka aborsi di Indonesia diperkirakan mencapai 2,3 juta pertahun, sekitar 750.000 diantaranya dilakukan oleh remaja, jumlah aborsi di Indonesia dilakukan oleh 2 juta orang tiap tahun dari jumlah itu dan 70.000 dilakukan oleh remaja putri yang belum menikah (Husain.RM,dkk,2014:1-7)

Data Indonesia menunjukkan bahwa remaja umur 15-19 tahun merupakan umur tertinggi baik wanita maupun pria yang melakukan hubungan seksual pertama kali. Hasil survey SDKI 2017 sebesar 74\% yang mengalami peningkatan 15\% dari hasil SDKI 2012 yaitu 59\%.(BKKBN,2017) Remaja yang sudah berkembang kematangan seksualnya, jika kurang mendapatkan pengarahan dari guru dan orangtua akan mudah terjebak dalam masalah. Masalah yang dimaksud dalam hal ini melakukan hubungan seks diluar nikah, penggunaan obat-obatan terlarang dan terjadi Kehamilan Tidak Diinginkan (KTD) yang berakhir melakukan aborsi.(Abrori,2014) Pada tahun 2015 Sulawesi Tengah jumlah remaja usia 10-19 tahun yang mengalami Kehamilan Tidak Diinginkan (KTD) 139 Orang, remaja bersalin 129 orang,(Dinas Kesehatan Sulawesi Tengah,2015) sedangkan Kota Palu di tahun yang sama menunjukkan bahwa remaja usia 10-19 tahun yang pernah melakukan hubungan seks pranikah 23 orang, KTD 29 orang, remaja yang bersalin 7 orang dan abortus pada remaja 26 orang.(Dinas Kota Palu,2015)

Berdasarkan hasil penelitian yang dilakukan oleh Fera Yulistina tentang Pengaruh Pendidikan Kesehatan Tentang Aborsi Terhadap Pengetahuan Dan Sikap Remaja Putri Di SMK Widya Praja Ungaran bahwa ada pengaruh pendidikan kesehatan terhadap pengetahuan remaja putri tentang aborsi dengan $p$ value $0,001<\alpha(0,05)$. Ada pengaruh pendidikan kesehatan terhadap sikap remaja putri tentang aborsi dengan $\mathrm{p}$ value $0,008<\alpha(0,05)$. (Yulista.F,2014)

Dalam penelitian Sukrillah menjelaskan bahwa berkembangnya media saat ini merupakan salah satu wujud era reformasi dan keterbukaan informasi. Bentuk perkembangan media komunikasi yang populer pada saat ini adalah whatsapp yang dapat digunakan untuk berbagi informasi ${ }^{(12)}$. Dikutip dari Detiknet "Pengguna whatsapp sebagai pesan instant terpopuler didunia telah mecapai 1 milliar pengguna aktif setiap harinya, rata-rata 1,3 milliar pengguna pengguna aktif menggunakan whatssap tiap bulan, dari 55 milliar pesan, 4,5 milliar diantaranya berupa foto, sementara 1 milliar adalah video, mayoritas pesan berupa tulisan, sedangkan di Indonesia pengguna whatssapp mencapai angka 58\%".(Yudhianto,2017)

Berdasarkan penelitian Wibisono tentang "Efektivitas penggunaan grup sosial media whatsapp sebagai media edukasi penanganan pertama cedera muskuloskeletal pada pelatih sepakbola" bahwa uji statistik menunjukan bahwa terdapat perbedaan signifikan antara sebelum dan sesudah intervensi $(p \leq 0,05)$. sehingga disimpulkan bahwa grup sosial media whatsapp dapat digunakan sebagai media edukasi penanganan pertama cedera muskuloskeletal pada pelatih sepakbola.(Wibisono.B.K,2017)

Tujuan penelitian adalah diketahuinya pengaruh edukasi tentang bahaya aborsi melalui layanan whatsapp terhadap peningkatan pengetahuan dan sikap remaja putri di SMA Negeri 3 Palu. Manfaat dilakukan penelitian yaitu remaja putri dapat mengetahui bahaya aborsi sehingga dapat mencegah terjadinya peningkatan perilaku aborsi di kalangan remaja putri.

\section{METODE}

Metode penelitian yang digunakan adalah pre eksperimen dengan rancangan the one group pretest-postest design. Penelitian ini dilaksanakan pada tanggal 22 April sampai dengan 13 Mei 2019 di SMA Negeri 3 Palu. Menggunakan rumus slovin dalam penentuan 
sampel dan diperoleh besar sampel 86 responden, pengambilan sampel dengan teknik stratified proportional random sampling. Tehnik pengumpulan data yaitu peneliti melakukan pretest dengan cara pengisian kuesioner di hari pertama sebelum dilakukan edukasi dan melakukan posttest dihari terakhir dengan cara pengisian kuesioner. Analisis data dalam penelitian ini adalah analisis univariat dan bivariat (uji wilcoxon).

\section{HASIL}

\section{Hasil Analisis Univariat}

Tabel 1.Karakteristik Responden Di SMA Negeri 3 Palu Tahun 2019

\begin{tabular}{|c|c|c|}
\hline Karakteristik & $\mathbf{f}$ & $\%$ \\
\hline \multicolumn{3}{|l|}{ 1. Umur } \\
\hline a. 15 tahun & 36 & 41,86 \\
\hline b. 16 tahun & 50 & 58,14 \\
\hline Jumlah & 86 & 100 \\
\hline 2. Kelas & & \\
\hline a. $X$ & 43 & 50 \\
\hline b. XI & 43 & 50 \\
\hline Jumlah & 86 & 100 \\
\hline
\end{tabular}

Berdasarkan tabel 1 bahwa responden yang diteliti dengan umur 15 tahun sebanyak 36 responden $(41,86 \%)$ dan responden yang berumur 16 tahun sebanyak 50 responden $(58,14 \%)$. Responden dengan kelas X berjumlah 43 responden $(50 \%)$ dan kelas XI berjumlah 43 responden $(50 \%)$.

Tabel 2. Distribusi Hasil Edukasi Tentang Bahaya Aborsi Melalui Layanan Whatsapp Terhadap Peningkatan Pengetahuan Remaja Putri Di SMA Negeri 3 Palu Tahun 2019

\begin{tabular}{clcccc}
\hline \multirow{2}{*}{ Pengetahuan } & \multicolumn{2}{c}{ Pretest } & \multicolumn{2}{c}{ Postest } \\
\cline { 2 - 6 } & f & \% & f & \% \\
\hline 1. & Baik & 73 & 84,88 & 82 & 95,35 \\
\hline 2. & Cukup & 13 & 15,12 & 4 & 4,65 \\
\hline 3. & Kurang & 0 & 0 & 0 & 0 \\
\hline & Jumlah & 86 & 100 & 86 & 100 \\
\hline
\end{tabular}

Berdasarkan tabel 2 menunjukkan bahwa tingkat pengetahuan remaja putri sebelum diberikan edukasi tentang bahaya aborsi melalui layanan whatsapp didapatkan sebanyak 73 responden berpengetahuan baik, 13 responden $(15,12 \%)$ berpengetahuan cukup dan tidak ada (0\%) responden berpengetahuan kurang. Setelah diberikan edukasi tentang bahaya aborsi melalui layanan whatsapp didapatkan sebanyak 82 responden $(95,35 \%)$ berpengetahuan baik, 4 responden $(4,65 \%)$ berpengetahuan cukup dan tidak ada (0\%) responden berpengetahuan kurang.

Tabel 3. Distribusi Hasil Edukasi Tentang Bahaya Aborsi Melalui Layanan Whatsapp Terhadap Peningkatan Sikap Remaja Putri Di SMA Negeri 3 Palu Tahun 2019

\begin{tabular}{lccccc}
\hline \multirow{2}{*}{ Sikap } & \multicolumn{2}{c}{ Pretest } & \multicolumn{2}{c}{ Postest } \\
\cline { 3 - 6 } & & f & \% & f & \% \\
\hline 1. & Positif & 49 & 56,98 & 57 & 66,28 \\
\hline 2. & Negatif & 37 & 43,02 & 29 & 33,72 \\
\hline & Jumlah & 86 & 100 & 86 & 100 \\
\hline
\end{tabular}

Berdasarkan tabel 3 menunjukkan bahwa sikap remaja putri sebelum diberikan edukasi tentang bahaya aborsi melalui layanan whatsapp didapatkan sebanyak 49 responden (56,98\%) yang memiliki sikap positif dan 37 responden $(43,02 \%)$ memiliki sikap negatif. Sedangkan sikap remaja putri setelah diberikan edukasi tentang bahaya aborsi melalui layanan whatsapp didapatkan sebanyak 57 responden $(66,28 \%)$ yang memiliki sikap positif dan 29 responden $(33,72 \%)$ memiliki sikap negatif.

Tabel 4. Distribusi Hasil Analisis Uji Wilcoxon Pengaruh Edukasi Tentang Bahaya Aborsi Melalui Layanan Whatsapp Terhadap Peningkatan Pengetahuan Remaja Putri di SMA Negeri 3 Palu Tahun 2019

\begin{tabular}{cccccccc}
\hline \multicolumn{2}{c}{ Variabel } & n & Mean & Min & Max & SD & $\boldsymbol{p}$ \\
\cline { 1 - 5 } $\begin{array}{l}\text { Pre- } \\
\text { test }\end{array}$ & 86 & 74,86 & 47 & 93 & 11,003 & \\
\cline { 1 - 5 } & $\begin{array}{l}\text { Post- } \\
\text { test }\end{array}$ & 86 & 81,45 & 53 & 93 & 9,641 & \\
\hline
\end{tabular}

Berdasarkan Tabel 4 menunjukkan bahwa terjadi peningkatan nilai rata-rata pengetahuan sesudah diberikan edukasi sebesar 6,59 (44 responden dengan nilai diatas 81,45). Nilai terendah atau nilai minimal sebelum diberikan edukasi yaitu 47 dan nilai tertinggi atau maksimal sebesar 93 dengan standar deviasi sebesar 11,003. Sesudah diberikan edukasi nilai minimal 
responden 53 dan nilai maksimal sebesar 93 dengan standar deviasi 9,641. Sehingga didapatkan significancy dengan uji wilcoxon nilai $p$-value 0,000 yang berarti $p$-value 0,000 $<0,05$ yang artinya bahwa terdapat pengaruh edukasi tentang bahaya aborsi melalui layanan whatsapp terhadap peningkatan pengetahuan remaja putri di SMA Negeri 3 Palu.

Tabel 5. Distribusi Hasil Analisis Uji Wilcoxon Pengaruh Edukasi Tentang Bahaya Aborsi Melalui Layanan Whatsapp Terhadap Peningkatan Sikap Remaja Putri Di SMA Negeri 3 Palu Tahun 2019

\begin{tabular}{|c|c|c|c|c|c|c|}
\hline Variabel & $\mathbf{n}$ & Mean & Min & Maks & $S D$ & $p$ \\
\hline $\begin{array}{ll}\text { 1. Pre- } \\
\text { test }\end{array}$ & 86 & 34,07 & 29 & 40 & 2,315 & \multirow{2}{*}{0,000} \\
\hline $\begin{array}{ll}\text { 2. } & \begin{array}{l}\text { Post- } \\
\text { test }\end{array} \\
\end{array}$ & 86 & 35,49 & 30 & 40 & 2,074 & \\
\hline
\end{tabular}

Berdasarkan Tabel 4.5 menunjukkan bahwa terjadi peningkatan nilai rata-rata sikap sesudah diberikan edukasi sebesar 1,42 (35 responden dengan nilai diatas 35,49). Nilai terendah atau nilai minimal sebelum diberikan edukasi yaitu 29 dan nilai tertinggi atau maksimal sebesar 40 dengan standar deviasi sebesar 2,315. Sesudah diberikan edukasi nilai minimal responden 30 dan nilai maksimal sebesar 40 dengan standar deviasi 2,074. Sehingga didapatkan significancy dengan uji wilcoxon nilai $p$-value 0,000 yang berarti $\mathrm{p}$-value $0,000<0,05$ yang artinya bahwa terdapat pengaruh edukasi tentang bahaya aborsi melalui layanan whatsapp terhadap peningkatan sikap remaja putri di SMA Negeri 3 Palu.

\section{PEMBAHASAN}

\section{Pengaruh Edukasi Tentang Bahaya Aborsi Melalui Layanan Whatsapp Terhadap Peningkatan Pengetahuan Remaja Putri}

Hasil analisis tabel 4 dari statistik dengan menggunakan uji wilcoxon diperoleh nilai $\mathrm{p}$ value $=0,000 \quad(p<0,05) \quad$ sehingga didapatkan hasil $\mathrm{H}_{\mathrm{a}}$ diterima dan $\mathrm{H}_{0}$ ditolak. Dapat disimpulkan terdapat pengaruh setelah diberikan edukasi melalui layanan whatsapp terhadap peningkatan pengetahuan remaja putri melalui layanan whatsapp, hal ini disebabkan dikarenakan informasi yang diberikan saat edukasi tersampaikan dengan baik, sehingga responden terpapar dengan informasi yang diberikan. Pengetahuan sangat erat kaitannya dengan pendidikan dan peningkatan pengetahuan tidak mutlak diperoleh di pendidikan formal, akan tetapi juga dapat diperoleh pada pendidikan nonformal. Pendidikan mempengaruhi proses belajar, semakin banyak informasi yang masuk maka semakin banyak pula pengetahuan yang didapat tentang kesehatan (Budiman \& Riyanto A,2003:53)

Penelitian ini sejalan dengan penelitian yang dilakukan oleh Galang hasil penelitian menujukan rata - rata tingkat pengetahuan siswi kelas VIII sebelum diberikan pendidikan kesehatan tentang kesehatan reproduksi remaja adalah sebesar 1.84 dan rata - rata pengetahuan siswi kelas VIII setelah diberikan pendidikan kesehatan sebesar 2.58 dengan nilai signifikan 0.000 atau $\mathrm{p}<0.05$.

Peningkatan pengetahuan juga didukung oleh penggunaan layanan whatsapp. Edukasi tentang bahaya aborsi yang dilakukan menggunakan layanan whatsapp dan memberikan point-point materi sehingga efektif dalam peningkatan pengetahuan siswi. Layanan whatsapp dapat menyajikan berbagai bentuk penyampaian pesan, baik dalam bentuk teks, gambar, word, powerpoint, voice note, dll yang memudahkan seseorang memahami isi materi. Dan edukasi merupakan upaya atau kegiatan untuk menciptakan perilaku masyarakat yang kondusif untuk kesehatan. Penggunaan sosial media sangat efektif dan dapat menciptakan kesempatan yang lebih banyak untuk berinteraksi, sehingga penggunaan sosial media sebagai media edukasi dapat digunakan sebagai media untuk berinteraksi serta berbagi informasi dan efektif untuk digunakan.(Gikas J \& Grant,2013:18-25)

Penelitian ini juga sejalan dengan penelitian tentang pengaruh pemberian informasi dengan media whatsapp terhadap pengetahuan remaja tentang HIV dan AIDS, menggunakan uji wilcoxon dengan hasil $p$ value sebesar 0,000 yang artinya bahwa terdapat pengaruh setelah dilakukan intervensi.(Kurniawati.HF \& Diniyah.K, 2018:259-264) 


\section{Pengaruh Edukasi Tentang Bahaya Bahaya Aborsi Melalui Layanan Whatsapp Terhadap Peningkatan Sikap Remaja Putri}

Hasil analisis tabel 5 dari uji statistik wilcoxon diperoleh nilai $p$-value $=0,000$ didapatkan hasil $\mathrm{H}_{\mathrm{a}}$ diterima dan $\mathrm{H}_{0}$ ditolak, dapat disimpulkan bahwa terdapat pengaruh edukasi terhadap peningkatan sikap remaja putri melalui layanan whatsapp. Terjadinya peningkatan sikap setelah diberikan edukasi kepada seluruh responden dikarenakan pengetahuan yang baik akan menimbulkan sikap yang positif pada seseorang. Hasil penelitian menyatakan bahwa berkembangnya media saat ini merupakan media komunikasi yang populer pada saat ini adalah whatsapp yang dapat digunakan untuk berbagi informasi.(Sukrillah. dkk,2017: 95-104). Pengetahuan merupakan hal yang penting dalam pembentukan tindakan seseorang, oleh sebab itu pengetahuan diperlukan sebagai dorongan psikis dalam menumbuhkan sikap dan perilaku.(Pengetahuan adalah dasar bagi seseorang untuk menentukan sikapnya, pengetahuan yang rendah maka akan berpengaruh pada sikap dan perilakunya mengenai suatu sesuatu hal akan rendah begitupu sebaliknya.(Notoatmotjo S,2012:4751)

Penelitian ini sejalan dengan penelitian hubungan tingkat pengetahuan remaja putri tentang aborsi dengan sikap remaja terhadap aborsi di MAN 2 Kediri Jawa Timur, menggunakan uji chi-square dengan hasil diperoleh $p$-value sebesar $\quad 0,027<0,05$ sehingga dapat disimpulkan ada hubungan antara tingkat pengetahuan remaja putri tentang aborsi dengan sikap remaja terhadap aborsi.

\section{SIMPULAN}

Edukasi tentang bahaya aborsi melalui layanan whatsapp mempunyai pengaruh terhadap peningkatan pengetahuan dan sikap remaja putri di SMA Negeri 3 Palu

\section{SARAN}

Bagi institusi Poltekkes kemenkes Palu diharapkan dapat melakukan edukasi kesehatan mengenai bahaya aborsi di sekolah yang belum terpapar edukasi tentang bahaya aborsi dan bagi sekolah agar guru-guru tetap memberikan informasi khususnya dalam peningkatan pengetahuan dan sikap serta pencegahan aborsi kepada semua siswi.

\section{UCAPAN TERIMA KASIH}

Ucapan terima kasih kepada : Nasrul, SKM., M.Kes selaku Direktur Politeknik Kesehatan Kemenkes Palu, H. Kasiludin Tahia, S.Pd., M.Pd selaku Kepala Sekolah SMA Negeri 3 Palu dan siswi SMA Negeri 3 Palu yang telah mendukung berlangsungnya penelitian ini.

\section{DAFTAR PUSTAKA}

Abrori. (2014). Di Simpang Jalan Aborsi : Sebuah Studi Kasus Terhadap Remaja Yang Mengalami Kehamilan Tak Diinginkan. Gigih Pustaka Mandiri : Semarang.

Ayu, S., \& Kurniawati, T. (2017). Hubungan Tingkat Pengetahuan Remaja Putri Tentang Aborsi Dengan Sikap Remaja Terhadap Aborsi Di MAN 2 Kediri Jawa Timur. Universitas Ahmad Dahlan: Jawa Timur.

BKKBN. (2017). Survey Demografi Kesehatan Indonesia 2017. Pusat penelitian dan pengembangan Kependudukan. https://cis.bkkbn.go.id/latbabang/wpdm pro=sdki-2017-kespro-remaja_versiindonesia. Diakses tanggal 20 September 2018.

Budiman \& Riyanto A. (2013). Kapita Selekta Kuesioner Pengetahuan Dan Sikap Dalam Penelitian kesehatan. Jakarta: Salemba Medika.

Dinkes Kota Palu. (2015). Laporan Kejadian Abortus Pada Remaja Di Kota Palu 2015. Palu.

Dinkes Provinsi Sulawesi Tengah (2015). Laporan Persalinan Pada Remaja Di Provinsi Sulawesi Tengah. Palu. 
Gikas, J. \& Grant, M.M (2013). Internet dan Pendidikan Tinggi. Hal 18-25

Husain, R.M., Kaeng, J.J., Suparman, E. (2014). Remaja Puteri Terhadap Bahaya Aborsi. Jurnal Kebidanan, 5(3), 1-7.

Kurniawati, H.F \& Diniyah, K. (2018). Pengaruh pemberian informasi dengan aplikasi whatsapp terhadap pengetahuan remaja tentang HIV dan AIDS di SMAn 1 Temon Kulon Progo Yogyakarta. Jurnal Kesehatan. 7(3), 259-264.

Notoatmodjo S. (2012). Promosi kesehatan dan perilaku kesehatan. Jakarta: PT Rineka Cipta.

Sukrillah, A. (2017). , IA Ratnamulyani 2 , AA Kusumadinata, 3(2), 95-104.

Wibisono, B. K. (2017). Efektivitas Penggunaan Grup Sosial Media Whatsapp Sebagai Media Edukasi
Penanganan Pertama Cedera Musculoskeletal Pada Pelatih Sepakbola. Yogyakarta: Program Studi Pendidikan Kepelatihan Olahraga Fakultas Ilmu Keolahragaan Universitas Negeri Yogyakarta.

Yudhianto. (2017). Penggunaan Whatsapp Kian Mencengangkan. DetikInet, hlm. 1. http://inet.detik.com/cyberlife/. Diakses tanggal 20 September 2018.

Yulista, F. (2014). Pengaruh Pendidikan Kesehatan Tentang Aborsi Terhadap Pengetahuan dan sikap Remaja Putri Tentang Aborsi Di SMK Widya Praja Ungaran. https://anzdoc.com/tingkatpengetahuan-remaja-putri-tentangbahaya-aborsi-di-ke.html. diakses tanggal 12 Februari 2019 jam 01.14 WITA. 